\title{
Investigation of tissue organelles by a combination of analytical subcellular fractionation and enzymic microanalysis: a new approach to pathology
}

\author{
TIMOTHY J PETERS \\ From the Division of Clinical Cell Biology, MRC Clinical Research Centre, Watford Road, Harrow, \\ HA1 3UJ, Middlesex, UK
}

SUMMARY Classical approaches to the study of pathological tissue have relied mainly on morphological techniques. In an attempt to quantitate the abnormalities and to investigate the pathogenesis of tissue disorders at a subcellular level we have combined analytical subcellular fractionation by sucrose density gradient centrifugation with microanalysis of tissue enzymic activities.

The methodological problems of performing these studies on milligram quantities of tissue are discussed. Details of the appropriate equipment are provided, and its application to the study of human liver specimens is described.

As an example of this approach, biochemical and subcellular fractionation experiments on tissue from patients with both primary and secondary hepatic lysosomal storage diseases are discussed. Examination of the lysosomal changes reveals that increased enzyme activity is a common finding in these disorders but tissue damage occurs only when there is evidence of enhanced lysosomal fragility with intracellular release of degradative enzymes. Other tissues which have proved amenable to study in this manner and in which profitable results in the investigation of their disorders have been obtained are listed.

Pathological study of tissue disorders has generally relied on morphological techniques, initially by light and, more recently, by electron microscopy. Important as these techniques are for diagnosis, they are essentially qualitative and provide little information on the functional status of the cells or of their individual organelles. In order to overcome these objections and to explore further the pathogenesis of disease mechanisms at a subcellular level, $\mathrm{I}^{1}$ have adopted a new quantitative biochemical approach to the study of tissue pathology. This approach combines a technique for analytical subcellular fractionation to separate the individual organelles with enzymic microanalysis to assay the activity of their marker enzymes and thereby to obtain quantitative information on the functional integrity of the organelles. It has a general applicability to all fields of pathological investigation where biopsy samples can be obtained. In this review I have considered mainly hepatic tissue and have further limited the

Accepted for publication 3 September 1980 discussion to a particular group of disorders. The general principles of organelle separation by sucrose density gradient centrifugation will be considered; the technical problems encountered, and the specialised equipment employed to overcome them, and the properties of the principal hepatic organelles will be described. The application of this approach will then be illustrated by studies on hepatic lysosomal disorders.

\section{Subcellular fractionation techniques}

Separation of the organelles from portions of routine percutaneous hepatic needle biopsy specimens weighing between 5 and $15 \mathrm{mg}$ required the development of specialised techniques. For several reasons it was decided to use a zonal centrifuge rather than a swinging bucket or angle head rotor. In particular, zonal centrifugation is considerably more rapid, an important consideration in studying pathological tissue when the organelles are likely to be particularly fragile. In addition, for technical reasons the 


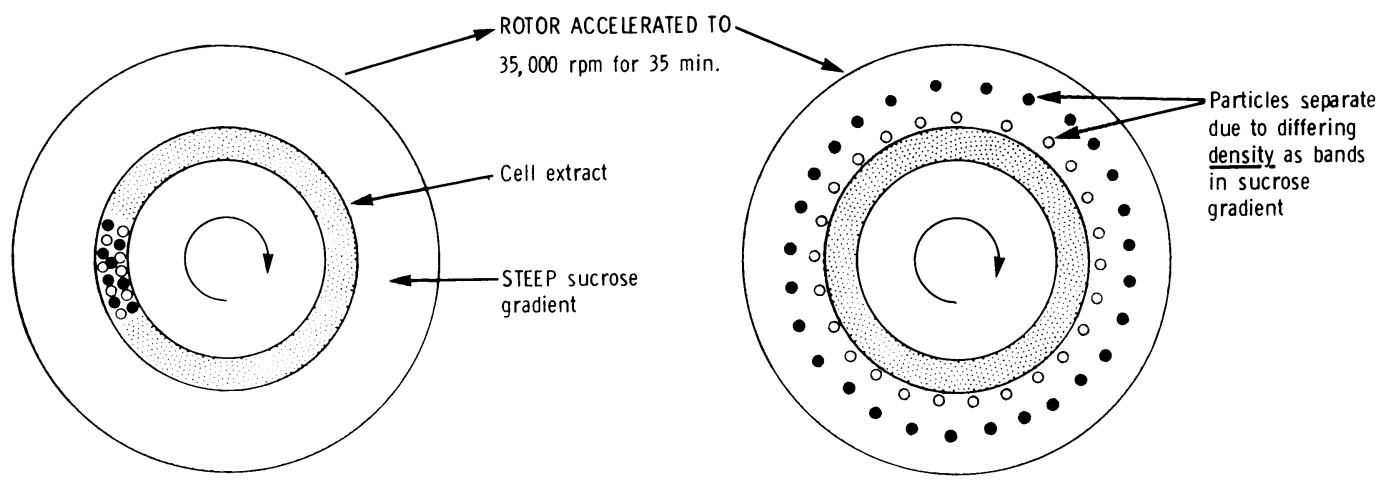

ROTOR LOADED AT 5,000 rpm

ROTOR UNLOADED AT 10,000 rpm

Fig. 1 Separation of subcellular organelles by isopycnic centrifugation in the Beaufay zonal rotor.

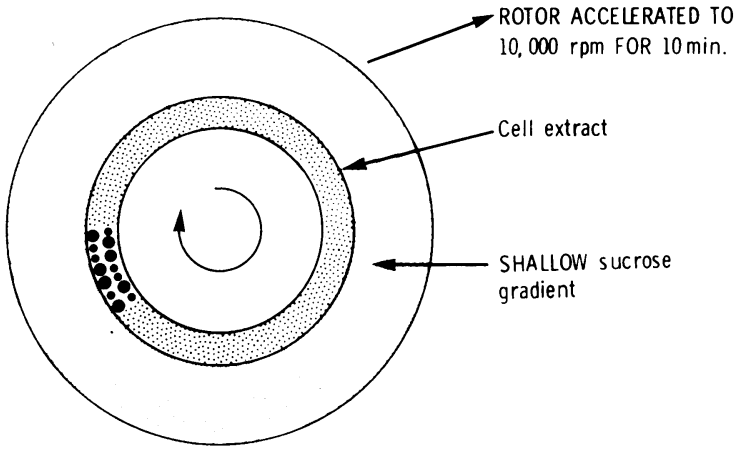

ROTOR LOADED AT 5,000 rpm

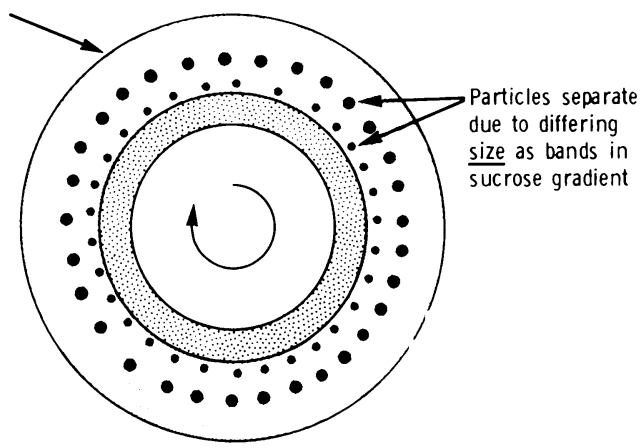

ROTOR UNLOADED AT $6,000 \mathrm{rDm}$

Fig. 2 Separation of subcellular organelles by isokinetic (rate zonal) centrifugation in the Beaufay rotor.

separation of the organelles is superior with this type of rotor. These rotors can be used in either the isopycnic or isokinetic modes, when the organelles are separated on the basis of, respectively, differences in density or size. Figures 1 and 2 illustrate the principles of these techniques in the zonal rotor. For routine purposes and in the examples to be described in this review, isopycnic centrifugation is used as the separations are more reproducible and the spread of densities of individual organelles is considerably less than the distribution of their sizes.

Unfortunately, none of the zonal centrifuges that are commercially available are suitable for use with milligram amounts of tissue; they were developed for processing up to $10 \mathrm{~g}$ quantities of material, having chamber volumes of approximately 1 litre. I was fortunate in having the facilities to construct the small-volume automatic zonal centrifuge and associated equipment described by Henri Beaufay of Louvain. This rotor has a volume of $35 \mathrm{ml}$ and therefore is particularly suitable for processing biopsy- sized fragments of tissue. In addition, it has specific features which minimise organelle damage, separating them in as short a time as 10 minutes, and gives complete recoveries of the various cell components. Figure 3 shows the rotor and filling unit aligned on the laboratory bench and illustrates how the filling unit can be engaged to the rotor cone by means of a gas-tight clutch. Figure 4 shows diagrammatically the different parts of the rotor and the associated equipment.

Having collected from the rotor a series of density gradient fractions, the distribution of the various organelles is determined in these fractions. Although ultrastructural examination of the fractions has been performed in order to assess the appearance of the isolated organelles, measurement is best performed by enzymic analysis. Again, because of the small amounts of tissue used and because of the dilution that occurs during the centrifugation procedure, it has been necessary to adopt highly sensitive assay procedures. ${ }^{2-4}$ Fluorigenic and radiolabelled sub- 


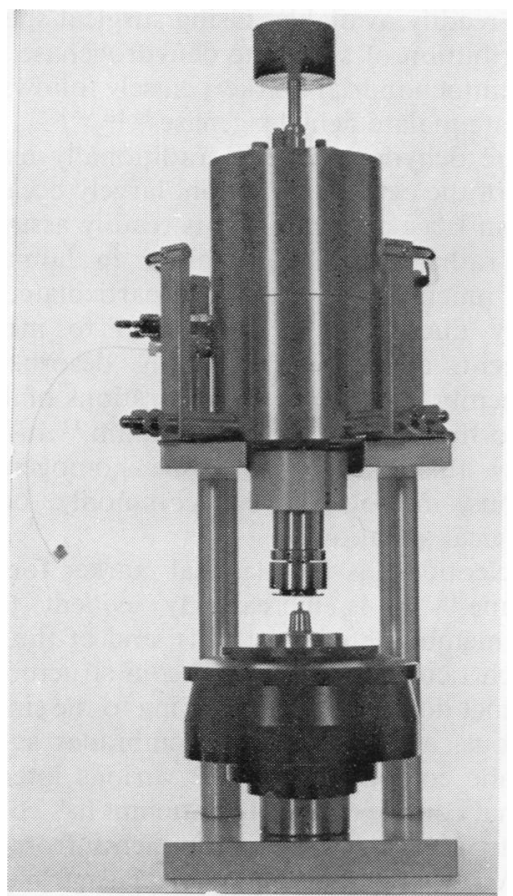

Fig. 3 Beaufay rotor and associated filling unit showing their relationship with the clutch-seal disengaged during high-speed centrifugation. During loading and unloading at low speed the clutch-seal assembly is mated to the rotor cone. strates have been used and, in certain instances, we have been forced to use marker enzymes for which there are suitably sensitive assays rather than the conventional organelle markers. Where necessary, these have been checked by studies on large biopsy specimens obtained at surgery.

\section{Analytical subcellular fractionation of control human liver}

The fragments of hepatic tissue are gently homogenised in $3 \mathrm{ml}$ isotonic sucrose. Routinely, $1 \mathrm{mM} \mathrm{Na} \mathrm{Na}_{2}$ EDTA is added to minimise enzyme inhibition and $20 \mathrm{mM}$ ethanol to stabilise the catalase content of the biopsy specimen. ${ }^{5} \mathrm{~A}$ lowspeed centrifugation step is usually included to sediment undisrupted cells and nuclei, and the postnuclear supernatant is injected into the rotor. More recently, after studies with rat liver, ${ }^{6}$ we have been fractionating the whole homogenate in a single step. Additional information on the properties of the nuclei can be obtained but, more importantly, sheets of plasma membrane which would normally sediment with the low-speed pellet can be studied in the gradient, and thus the enzyme distributions in these studies more closely reflect the plasma membrane properties of the whole biopsy specimen. This fractionation of whole homogenates considerably speeds up the processing time, and it is especially important in cells with marked regional variation in

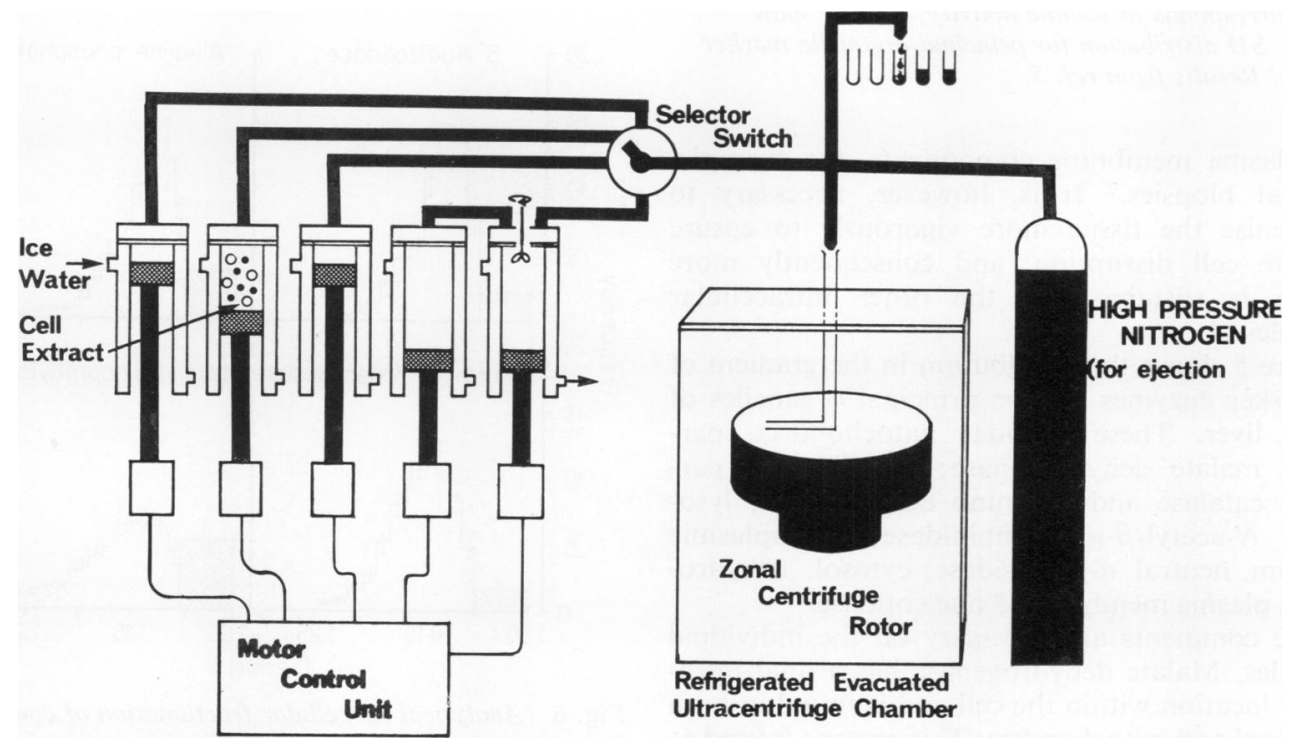

Fig. 4 Essential components of centrifugation equipment. The various syringes of the gradient-making and sample-loading pumps are connected via a selector switch to a multiport valve which allows, successively, filling of the rotor, injection of nitrogen after the high-speed centrifugation, and collection of the gradient fractions. 


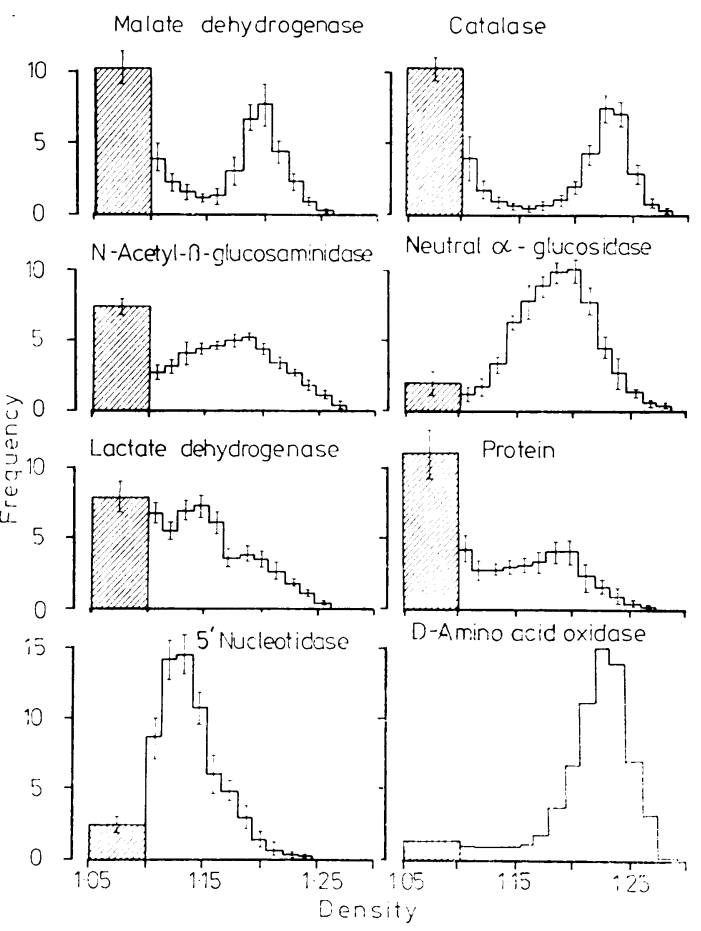

Fig. 5 Analytical subcellular fractionation of control human liver biopsy extracts. Activity (frequency) is plotted against gradient density [see ref. 8]. The activity between densities 1.05 and $1.10 \mathrm{~g} / \mathrm{cm}^{3}$ corresponds to the sample layer. Enzymic activity in this region corresponds to soluble activity. Results show mean $\pm S D$ distribution for principal organelle marker enzymes. Results from ref. 5 .

their plasma membrane components, for example, intestinal biopsies. ${ }^{7}$ It is, however, necessary to homogenise the tissue more vigorously to ensure complete cell disruption, and consequently more damage is sustained by the other intracellular organelles.

Figure 5 shows the distribution in the gradient of the marker enzymes for the principal organelles of human liver. These include: mitochondria, particulate malate dehydrogenase; peroxisomes, particulate catalase and D amino acid oxidase; lysosomes, $N$-acetyl- $\beta$-glucosaminidase; endoplasmic reticulum, neutral $\alpha$-glucosidase; cytosol, dehydrogenase; plasma membrane, 5'nucleotidase.

Some comments are necessary on the individual organelles. Malate dehydrogenase has a dual intracellular location within the cell and is found in both the cytosol and mitochondria. This enzyme is used as a marker because it is present at high concentrations within the cell, and a highly sensitive fluorimetric assay is readily available. Using surgical specimens, the distribution of succinate dehydrogenase, a more specific mitochondrial marker, closely follows that of particulate malate dehydrogenase. ${ }^{9}{ }^{10}$

Lactate dehydrogenase is traditionally used as a marker of the cytosolic fraction, largely because it is present in large amounts and is readily assayed, but it is a rather unsuitable marker in human liver because much of the activity is particulate. This is probably due to ionic adsorption to membrane components as it can be readily desorbed from these membranes if low concentrations of $\mathrm{KCl}$ are added to the homogenisation medium. ${ }^{11}$ It is useful to assay this enzyme in tissue homogenates as alterations in total levels commonly occur in pathological situations.

$5^{\prime}$ Nucleotidase is the classical marker for plasma membrane. ${ }^{12}$ It is increasingly evident that the plasma membrane of most cells, and of the hepatocyte in particular, is a heterogeneous structure. There are distinct domains corresponding to the sinusoidal, contiguous, and canalicular membranes as well as membrane components of the various intercellular junctional complexes. ${ }^{13}$ Little attempt has been made so far to separate these components from human liver. Assay of four putative plasma membrane marker enzymes in the gradient fractions does, however, show significant differences between their distributions (Fig. 6). In particular, $\gamma$-glutamyl transpeptidase has a consistently higher modal density, and it is suggested that this enzyme is

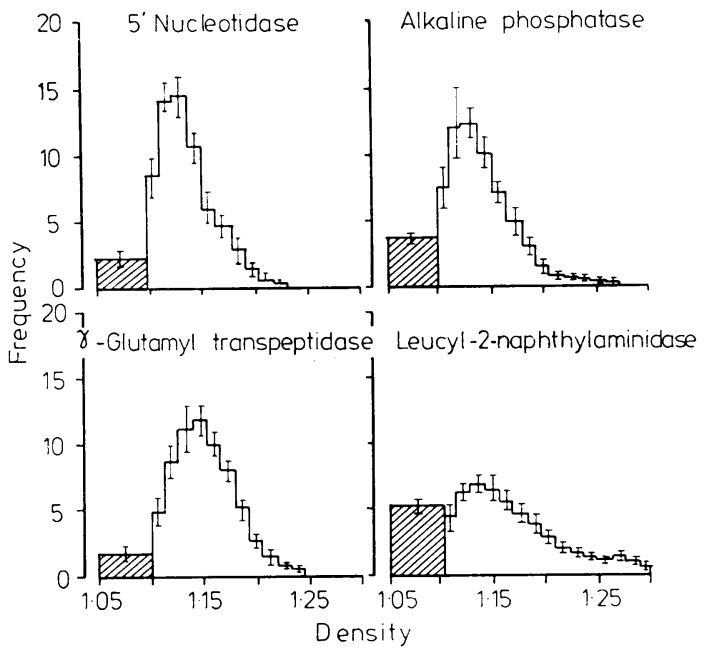

Fig. 6 Analytical subcellular fractionation of control liver biopsy extracts. Distributions of four putative plasma membrane markers are compared. Legend as for Fig. 5. 


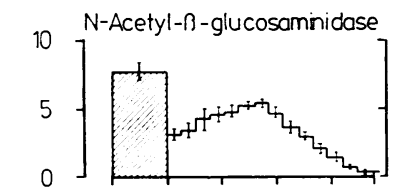

ก-Glucuronidase

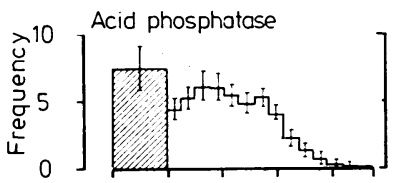
$\alpha$-Galactosidase

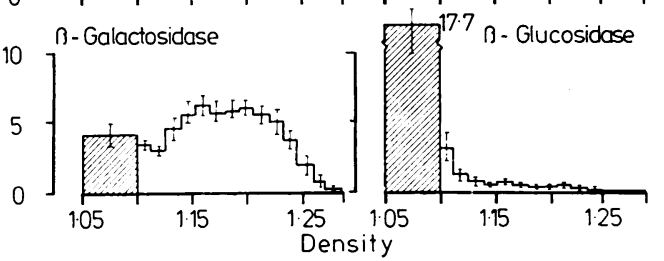

Fig. 7 Analytical subcellular fractionation of control liver biopsy extracts. Distribution of six putative lysosomal marker enzymes. Legend as for Fig. 5.
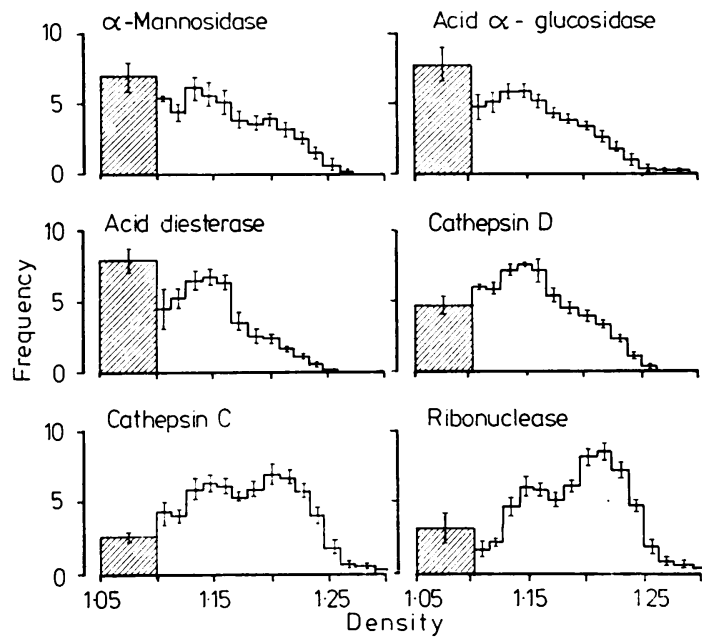

Fig. 8 Analytical subcellular fractionation of control liver biopsy extracts. Distribution of six putative lysosomal marker enzymes. Legend as for Fig. 5.

selectively located in the biliary canaliculus. ${ }^{14}$ Another source of heterogeneity is the multiplicity of cell types in the liver biopsy. Although parenchymal, Kupffer, and biliary tract cells have been reliably separated from the livers of experimental animals ${ }^{15} 16$ and from post-mortem human tissue, ${ }^{17}$ this is not yet possible with biopsy specimens. Certain enzymes, for example, acid phosphatase and $\beta$-glucuronidase, are present in higher concentrations in Kupffer than in parenchymal cells, ${ }^{16}$ and this probably reflects, in part, their differential responses in disease situations.
Figures 7 and 8 show the gradient distribution of 12 acid hydrolases, putative lysosomal enzymes. They clearly have different distributions, and $\beta$-glucosidase, claimed to be present in lysosomes of rat liver, ${ }^{18}$ has a negligible localisation to this organelle in man when assayed with this substrate. Close inspection of the distribution suggests that there are two populations of lysosomes of differing densities. Some enzymes, for example, acid diesterase and cathepsin $\mathrm{D}$, are found to a greater extent in the low-density population. Ribonuclease is present in a higher proportion in the high-density population but most enzymes are more or less equally distributed between the two populations. This dual localisation may in part reflect the Kupffer cells' lysosomes contributing predominantly to the low-density fractions.

One problem with analytical subcellular fractionation is that, although the profiles are usually quite distinct, there is incomplete separation of certain of the organelles in the sucrose gradients. Thus, in Fig. 5 the modal densities of particulate malate dehydrogenase and of $N$-acetyl- $\beta$-glucosaminidase are similar although their distributions are markedly different. This resolution of the organelles can be enhanced by the use of selective membrane perturbants, and this is illustrated in Figure 9. Homogenisation of the tissue in isotonic sucrose containing low concentrations of digitonin has highly specific effects on the various organelles. Plasma membrane components, 5'nucleotidase and $\gamma$-glutamyl transpeptidase, show a marked increase in equilibrium density. Digitonin, a dense carbohydratecontaining sterol, binds very tightly to the free cholesterol present in the membrane, ${ }^{19} 20$ causing an increase in their equilibrium density. In addition, the detergent action of digitonin strips protein and RNA from the endoplasmic reticulum, reducing its density, and therefore its marker enzyme is shifted to lighter fractions. ${ }^{20}$ Lysosomal membranes are solubilised by digitonin and therefore the contents of this organelle are released into the cytosol during the homogenisation procedure. On subsequent centrifugation, all the activity remains in the sample layer with no enzyme within the gradient. ${ }^{5}$ In contrast, mitochondrial and peroxisomes are unaffected (not shown). Thus clear resolution of the lysosomal and mitochondrial components has been achieved.

A further example is also illustrated in Figure 9. Pyrophosphate has a highly selective effect on endoplasmic reticulum (ER), stripping off the ribosomes. The distribution of the ER is largely determined by its degree of granulation with ribosomes, that is, the relative proportion of so-called rough ER. ${ }^{21}$ Therefore removal of the ribosomes leads to a marked decrease in the median density of 


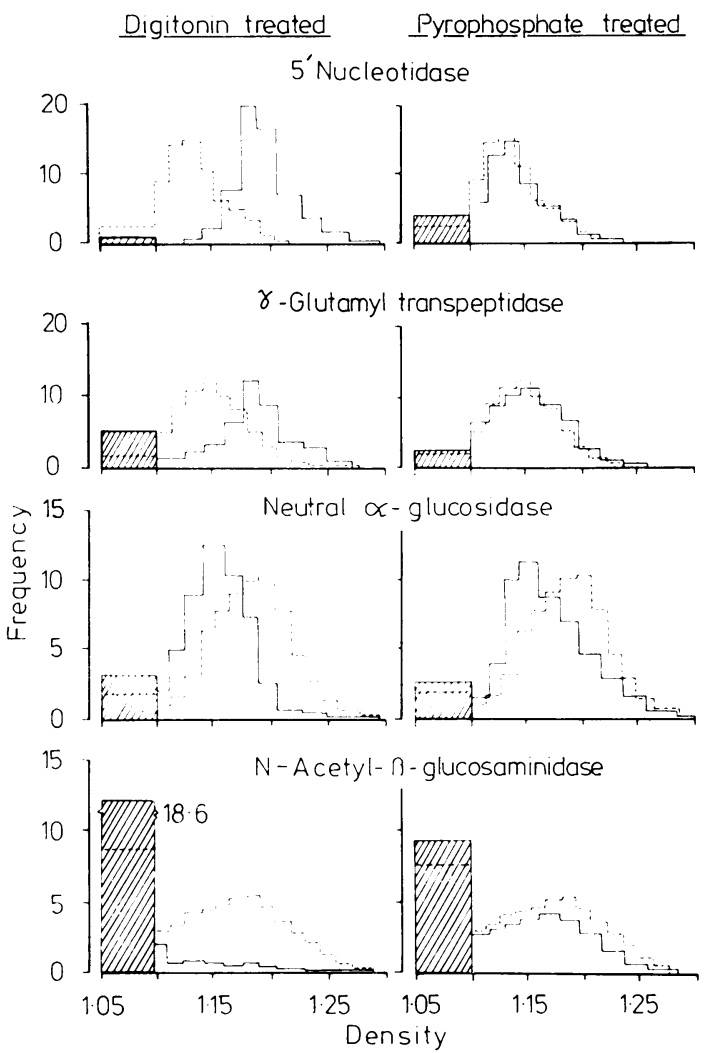

Fig. 9 Effect of digitonin or pyrophosphate on plasma membrane (5'nucleotidase, $\gamma$-glutamyl transpeptidase), endoplasmic reticulum (neutral $\alpha$-glucosidase), and lysosomal (N-acetyl- $\beta$ glucosaminidase) enzyme distributions. Legend as for Fig. 5. Control (----) and treated (- -) homogenates.

the membranous neutral a-glucosidase. The distribution of this enzyme in the gradient thus reflects, in a quantitative manner, the proportions of rough and smooth in the liver cell. Thus in alcoholic liver disease and Gilbert's disease where there is an increase in the proportion of the ribosome-free ER, there is a decrease in the density distribution of membranebound $\alpha$-glucosidase. ${ }^{22} 23$

\section{Subcellular fractionation studies in lysosomal storage} diseases

Lysosomal storage disease usually refers to the rare group of inborn errors of metabolism in which one of the 50 or so lysosomal enzymes is congenitally absent with consequent accumulation of its substrate. This group of disorders is more correctly referred to as primary lysosomal diseases. Far more common are the secondary lysosomal diseases in which there is no primary intrinsic abnormality in the lysosomes but, because of other factors, there is accumulation of relative bio-undegradable material within these organelles. Only some of these secondary lysosomal disorders are associated with tissue damage. Table 1 shows the activities of several acid hydrolases in liver biopsy specimens from patients with primary or secondary lysosomal storage diseases. It is clear that in all these disorders the activity of all or most of the acid hydrolases is elevated. This appears to be independent of whether the disease is associated with liver damage (Pompe's disease, iron overload, primary biliary cirrhosis) or not (Dubin-JohnsonSprinz syndrome, Gilbert's disease). It probably does correlate roughly with the degree of lysosomal accumulation of undegradable material. In Gilbert's disease there is minimal accumulation of lipofuschin in lysosomes; $;^{29-31}$ the acid hydrolases are minimally elevated. In contrast, in Pompe's disease there is gross distension of the lysosomes with glycogen due to a congenital absence of lysosomal acid maltase. ${ }^{32}$

The studies in patients with iron overload are of interest. Three of the four acid hydrolases are elevated; $\beta$-glucuronidase activity is, however, normal. This may indicate little accumulation of iron in the Kupffer cells, which are rich in this enzyme. ${ }^{101633}$ This conclusion is in contrast to the classical pathological teaching that in primary haemochromatosis iron loading is predominantly in

Table 1 Activity of lysosomal enzymes in human liver biopsy specimens

\begin{tabular}{|c|c|c|c|c|}
\hline Diagnosis & $\begin{array}{l}\mathrm{N}-\text { Acetyl- } \beta- \\
\text { glucosaminidase }\end{array}$ & Acid phosphatase & $\beta$-Glucuronidase & $\beta$-Galactosidase \\
\hline Control $^{5}$ & $2.03 \pm 0.28$ & $12.9 \pm 0.81$ & $4.92 \pm 0.40$ & $0.420 \pm 0.120$ \\
\hline Primary biliary cirrhosis ${ }^{25}$ & $4 \cdot 3 \pm 0 \cdot 7$ & $25 \cdot 4 \pm 3 \cdot 1$ & - & - \\
\hline Dubin-Johnson-Sprinz syndrome ${ }^{26} 27$ & $7 \cdot 10$ & $31 \cdot 5$ & $16 \cdot 3$ & - \\
\hline Gilbert's disease ${ }^{23}$ & $3.37 \pm 0.26$ & $19 \cdot 3=1 \cdot 3$ & $8.66 \pm 0.72$ & - \\
\hline Secondary haemochromatosis ${ }^{28}$ & $5.82 \pm 0.79$ & $45 \cdot 2 \pm 5 \cdot 9$ & $4.43 \pm 0.95$ & $2 \cdot 16 \pm 0.64$ \\
\hline Treated primary haemochromatosis ${ }^{28}$ & $2.96 \pm 0.44$ & $13.4 \pm 2 \cdot 5$ & $4.06 \pm 0.95$ & $0.401 \pm 0.093$ \\
\hline
\end{tabular}

Mean \pm SE lysosomal enzyme activities in tissue extracts from control and pathological tissue. Activities expressed as mUnits/mg protein where $1 \mathrm{mUnit}$ corresponds to the hydrolysis of $1 \mathrm{nmol}$ substrate/min. Results taken from appropriately noted reference. 
parenchymal cells whereas in secondary haemochromatosis the excess iron is found in Kupffer cells. It is of interest that for two of the enzymes the acid hydrolase levels are greater in secondary than in primary haemochromatosis. This does not reflect the degree of iron loading or correlate with the degree of damage. ${ }^{28}$ The observation that the activities return to control values after removal of the excess iron indicates that these lysosomal changes are secondary events.

Increased levels of a range of lysosomal enzymes have previously been noted in primary lysosomal storage diseases. ${ }^{34}$ Similarly, in experimental storage diseases, increased levels of acid hydrolases have been noted ${ }^{35-37}$ The mechanism of, and reason for, this increased activity are uncertain. A trite explanation is that it is a normal response by the cell to degrade the accumulated material. Such a mechanism has been demonstrated for macrophages. ${ }^{38}$

It is not clear whether the accumulation of undegradable material alone leads to tissue damage. Certainly, Gilbert's disease and Dubin-Johnson-

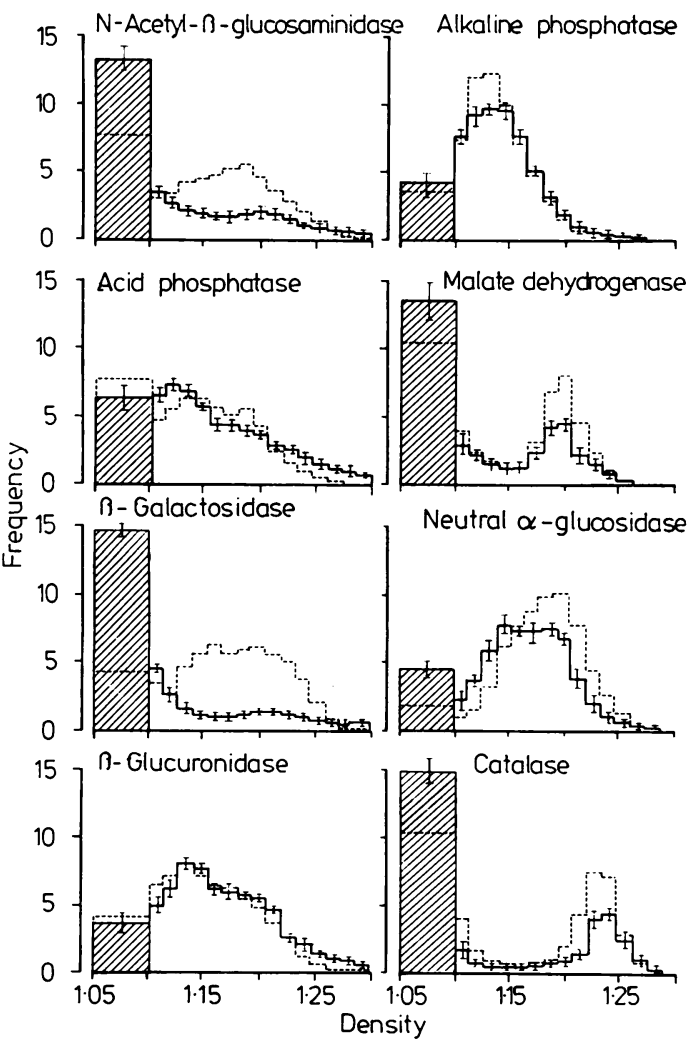

Fig. 10 Comparison of principal organelle marker enzyme distribution from control (----) and iron-overloaded tissue (-). Legend as for Fig. 5. Results from ref. 28.
Sprinz syndrome are not associated with significant hepatic damage. It is likely, however, that the progressive accumulation of undegradable lipofuschin or melanin pigments with age may reduce the capacity of hepatic lysosomes to perform their normal role of turnover of the subcellular components.

A key factor of the lysosomal role in the pathogenesis of tissue damage is the maintenance of lysosomal membrane integrity. If, in spite of accumulating material, the membrane remains intact it is unlikely that leakage of degradative enzymes into the cell sap will occur. This concept was originally put forward as the 'suicide-bag' hypothesis, ${ }^{39}$ which, with modification, is still tenable. In order to investigate this hypothesis in human liver diseases it is necessary to determine the integrity of lysosomes in the cell extracts. This information can be obtained from inspection of the sucrose density gradient enzyme distributions or from measurements of latent lysosomal enzyme activities.

Figure 10 compares the gradient distributions of the various organelle markers in control and ironoverloaded tissue. There are distinct differences in the distributions of both $N$-acetyl- $\beta$-glucosaminidase and $\beta$-galactosidase. In the iron-loaded patients, very little enzyme is particle-bound, most of the activity remaining in the sample layer. This is because the fragile iron-laden lysosomes have lost most of their enzymes during the homogenisation and centrifugation procedures. Note, however, that the distributions of acid phosphatase and $\beta$-glucuronidase are unaffected. This is further evidence that they are located predominantly in a distinct population of lysosomes. Similar results are found in patients with untreated primary haemochromatosis. These abnormalities revert to normal after removal of the excess iron by venesection. ${ }^{28}$ Close inspection of the histograms reveals minor abnormalities in other organelles. There is a small loss of particulate malate dehydrogenase and catalase. This would be consistent with damage to mitochondria and peroxisomes, respectively, possibly due to the released lysosomal enzymes. Similar results are found when biopsy specimens from patients with primary haemochromatosis are studied, and the lesions are reversed by removal of the iron.

Figure 11 compares the organelle marker enzyme distributions for a biopsy specimen from a child with Pompe's disease, a primary lysosomal storage disorder, with control tissue. Similar results are noted to those found in patients with iron overload. There is loss of sedimentable $N$-acetyl- $\beta$-glucosaminidase and $\beta$-galactosidase with little effect on the other two acid hydrolases. Similarly, there is a decrease of mitochondrial and peroxisomal enzymes. It is known that 


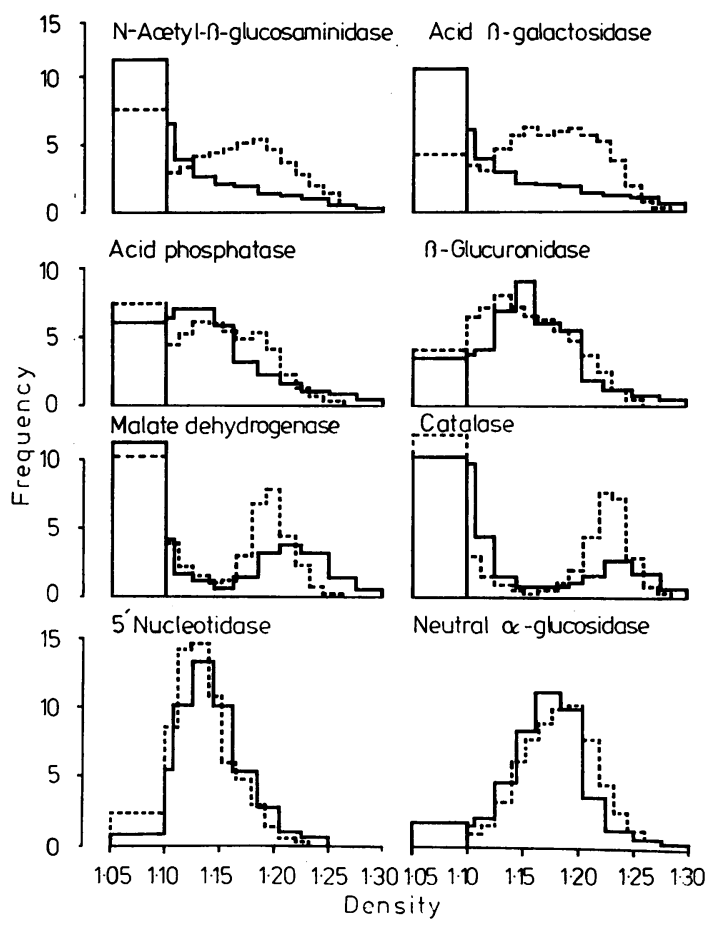

Fig. 11 Comparison of principal organelle marker enzyme distributions from control tissue (----) and liver biopsy specimen from a patient with Pompe's disease (-). Legend as for Fig. 5. Results from ref. 24.

in vitro lysosomal enzymes will rapidly impair mitochondrial function..$^{40}$ It is therefore likely that in vivo release of lysosomal enzymes into the cytoplasm could similarly interfere with mitochondria with catastrophic effects on cell function. Note that the plasma membrane, 5'nucleotidase, and endoplasmic reticulum, neutral $\alpha$-glucosidase, are unaffected.

We thus formulate the hypothesis that in order that lysosomal storage diseases cause cell damage there must be increased fragility of the organelles with subsequent release of enzymes; a mere increase in enzyme activity alone is insufficient. Information on lysosomal integrity can, however, be obtained without recourse to complex centrifugation procedures. Two such methods are illustrated in Figure 12. The fresh biopsy fragments are homogenised in isotonic sucrose and, by low-speed centrifugation, a post-nuclear supernatant (PNS fraction) is prepared. In the first technique the lysosomal suspension is assayed for latent lysosomal enzyme activity by incubating the suspension with buffered substrate in isotonic sucrose for short periods. The lysosomal membrane is impermeable to the substrate and therefore intralysosomal enzyme activity is not measured. Enzyme which has been released from the lysosomes
1. PNS fraction incubated with buffered substrate in isotonic sucrose $=$ FREE ACTIVITY.

PNS fraction incubated with buffered substrate in isotonic sucrose containing $0.1 \%$ Triton $x 100$ - TOTAL ACTIVITY.

\% Latency $=\frac{\text { Total }- \text { Free }}{\text { Total }} \times 100$

2. PNS fraction centrifuged at $20,000 \mathrm{~g} \times 20 \mathrm{~min}$. to sediment lysosomes.

\% Sedimentable $=$ Activity in Lysosomal Fraction $\times 100$ Total Recovered Activity

Fig. 12 Two methods of assessing lysosomal integrity by measuring latent and sedimentable acid hydrolase activities. The post nuclear supernatant (PNS fraction) is obtained by low-speed centrifugation of the liver homogenate.

(free activity) is readily assayable. Total enzyme activity in the suspension is determined by adding Triton X100, a detergent, to the buffered substrate which disrupts all the lysosomes, releasing their enzymic content into the incubation medium. The second method assays the lysosomal membraneassociated enzyme activity by subjecting the organelle suspension to high-speed sedimentation. The pellet is resuspended and assayed for enzyme activity in the presence of Triton X100. The percent sedimentable activity, like the percent latent activity, is a simple assay of lysosomal integrity.

Table 2 shows the application of these methods to biopsy specimens from patients with putative lysosomal storage diseases. In Pompe's disease there is a marked loss of latent activity, and this is associated with tissue damage. Similarly, in haemochromatosis, reduced latent and sedimentable activity are associated with severe tissue damage. Note that the acid phosphatase-containing lysosomes are unaffected; similar conclusions are reached by sucrose gradient centrifugation (Fig. 10). In contrast, tissue from patients with Gilbert's disease or with Dubin-Johnson-Sprinz syndrome showed normal lysosomal integrity, and liver damage does not occur in these disorders. Primary biliary cirrhosis is an apparent exception. There is a small but statistically insignificant decrease in lysosomal integrity but these patients invariably have liver damage. The extreme chronicity of the disorder may be reflected by the minimal loss of lysosomal integrity. Alternatively, it is possible that lysosomes are not implicated in the pathogenesis of the tissue damage. Copper accumulation in parenchymal cell lysosomes occurs only late in the disease 4142 and presumably does not alter their membrane permeability. Similar conclusions have been reached for patients with Wilson's disease. ${ }^{43} 44$ 
Table 2 Lysosomal integrity in human liver biopsy specimens

\begin{tabular}{|c|c|c|c|c|c|}
\hline Diagnosis & $\begin{array}{l}\text { Latent } \mathrm{N} \text {-acetyl- } \beta \text { - } \\
\text { glucosaminidase }\end{array}$ & $\begin{array}{l}\text { Sedimentable } \\
\text { N-acetyl- } \beta- \\
\text { glucosaminidase }\end{array}$ & $\begin{array}{l}\text { Latent acid } \\
\text { phosphatase }\end{array}$ & $\begin{array}{l}\text { Sedimentable acid } \\
\text { phosphatase }\end{array}$ & $\begin{array}{l}\text { Tissue damage with } \\
\text { functional } \\
\text { impairment }\end{array}$ \\
\hline $\begin{array}{l}\text { Control }^{5} \\
\text { Pompe's disease }{ }^{24} \\
\text { Primary biliary cirrhosis }{ }^{25}\end{array}$ & $\begin{array}{l}64 \cdot 7 \pm 1 \cdot 7 \\
23 \cdot 5 \\
47 \cdot 0 \pm 3 \cdot 4 \\
P>0 \cdot 05\end{array}$ & $\begin{array}{l}56 \cdot 1 \pm 2 \cdot 8 \\
-\end{array}$ & $\begin{array}{l}55 \cdot 4 \pm 3 \cdot 9 \\
-\end{array}$ & $\begin{array}{l}50 \cdot 6 \pm 2 \cdot 8 \\
-\end{array}$ & $\begin{array}{l}\overline{\text { Yes }} \\
\text { Yes }\end{array}$ \\
\hline $\begin{array}{l}\text { Dubin-Johnson-Sprinz } \\
\text { syndrome } \\
\text { Gilbert's disease }^{23}\end{array}$ & $\begin{array}{l}51 \cdot 5 \\
62 \cdot 6 \pm 2 \cdot 7 \\
P>0.05\end{array}$ & $\begin{array}{l}52 \cdot 8 \\
59 \cdot 5 \pm 6 \cdot 0\end{array}$ & $\overline{-}$ & $\overline{-}$ & $\begin{array}{l}\text { No } \\
\text { No }\end{array}$ \\
\hline $\begin{array}{l}\text { Secondary } \\
\text { haemochromatosis }{ }^{28}\end{array}$ & $\begin{array}{l}33.3 \pm 2.2 \\
P<0.001\end{array}$ & $\begin{array}{l}31 \cdot 5 \pm 2 \cdot 6 \\
P<0.001\end{array}$ & $\begin{array}{l}46 \cdot 9 \pm 2 \cdot 8 \\
P>0 \cdot 05\end{array}$ & $\begin{array}{l}46 \cdot 2 \pm 3.0 \\
P>0.05\end{array}$ & Yes \\
\hline $\begin{array}{l}\text { Untreated primary } \\
\text { haemochromatosis }\end{array}$ & $\begin{array}{l}35.5 \pm 3.3 \\
P<0.001\end{array}$ & $\begin{array}{l}33.0 \pm 2.0 \\
P<0.001\end{array}$ & $45 \cdot 3$ & $\begin{array}{l}44 \cdot 6 \pm 2 \cdot 9 \\
P>0 \cdot 05\end{array}$ & Yes \\
\hline
\end{tabular}

Mean $\pm \mathrm{SE}$ latent and sedimentable lysosomal enzyme activities in tissue extracts from control and pathological tissue. Results taken from appropriately noted reference.

Figure 13 shows sequential measurements of latent $N$-acetyl- $\beta$-glucosaminidase in five patients with primary haemochromatosis before and after removal of the iron overload by repeated venesection. Before treatment all patients showed impaired lysosomal integrity, but after treatment the values returned to control levels. Removal of the iron is accompanied by an improvement in liver function. The cause of the lysosomal disruption is uncertain. Ultrastructural studies ${ }^{45-47}$ show the accumulation of dense deposits of haemosiderin in the parenchymal cell lysosomes, and biochemical studies show a correlation between haemosiderin content of the tissue and impairment of lysosomal integrity. ${ }^{48}$ Studies in patients with primary treated haemochromatosis also implicate haemosiderin rather than ferritin in the lysosomal disruption.

The mechanism of the haemosiderin-mediated lysosomal disruption is unknown. Some mechanical

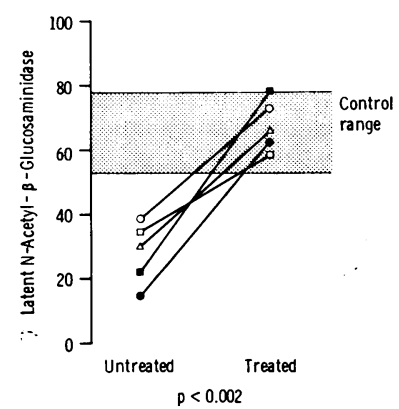

Fig. 13 Sequential assays of latent N-acetyl- $\beta$ glucosaminidase as a measure of lysosomal integrity in five patients with primary haemochromatosis before and after removal of the excess tissue iron by repeated venesection. Data from ref. 45. damage undoubtedly occurs to lysosomes during their isolation from human tissues, and it is likely that in iron-laden tissues this is increased. The mechanical effects of haemosiderin alone cannot account for the lysosomal disruption. ${ }^{47}$ Attempts to implicate iron-catalysed free radical-mediated lysosomal damage ${ }^{49-51}$ in man, albeit indirectly, have so far been unsuccessful, ${ }^{10}$ and the question remains unanswered for future studies.

This review has shown how simple biochemical studies on biopsies of human tissue can yield useful information on the pathogenesis of several disorders. Measurements of tissue enzyme activities would seem to be a more direct and sensitive index of tissue damage and response to treatment than assays of plasma enzyme activities, and there is some evidence that this is so. ${ }^{52}$ The assay and subcellular fractionation techniques can be readily applied to many tissues, and we have studied the following organs in this manner: stomach:53 jejunum ; ${ }^{75-58}$ rectum; $; 960$ myocardium; $; 164$ brain; ${ }^{65}$ skeletal muscle $; 6$ pituitary $;{ }^{67}$ pancreas. ${ }^{68}$ In addition, these techniques are clearly useful in the study of circulating cells and their disorders. Most extensive studies have been performed on neutrophils ${ }^{69-74}$ but monocytes $^{75}$ and lymphocytes ${ }^{76}$ have been similarly studied. Studies in experimental ${ }^{37}{ }^{77-80}$ and naturally occurring 8182 animal disease are also feasible, providing valuable information on the nature of the disorders.

Although the zonal centrifuge and associated equipment had to be constructed, ${ }^{83}$ commercially available centrifuges, particularly the recently introduced reorientating rotors, can produce similar separations. ${ }^{84} 85$ The use of density gradient media, other than sucrose, have not proved particularly useful. ${ }^{78086}$ As most of the principal marker enzymes 
have been fully characterised, valuable information on a variety of diseases can undoubtedly be obtained by assays on whole tissue homogenates or after simple centrifugation procedures. ${ }^{87-89}$ Most of the assays are easily performed and can often be adapted from routine clinical chemistry procedures, particularly those in use in paediatric departments. It is predicted that this application of techniques, which have hitherto been the province of the ratorientated cell biologist, will prove a valuable aid to laboratory diagnosis and assessment as well as a useful approach for the strictly research-orientated clinical investigator.

I am grateful to Dr G Slavin for helpful comments and suggestions, to a succession of research fellows, students, and technicians for invaluable contributions to this research programme, and to Ms Rosamund Greensted for typing the manuscript.

\section{References}

${ }^{1}$ Peters TJ. Application of analytical subcellular fractionation techniques and tissue enzyme analysis to the study of human pathology. Clin Sci Mol Med 1977;53: 505-11.

${ }^{2}$ Peters TJ, Müller M, De Duve C. Lysosomes of the arterial wall. I Isolation from normal rabbit aorta. $J$ Exp Med 1972;136:1117-39.

${ }^{3}$ Peters TJ, Shio H. Analytical subcellular fractionation studies of rat liver and on isolated jejunal enterocytes with special reference to the separation of lysosomes, peroxisomes and mitochondria. Clin Sci Mol Med 1976; 50:355-66.

4 Seymour CA, Peters TJ. Enzyme levels in human liver biopsies. Assay methods and activities of some lysosomal and membrane-bound enzymes in control tissue and serum. Clin Sci Mol Med 1977;52:229-39.

${ }^{5}$ Peters TJ, Seymour CA. Analytical subcellular fractionation of needle biopsy specimens from human liver. Biochem J 1978;174:435-46.

${ }^{6}$ Smith GD, Peters TJ. Analytical subcellular fractionation of rat liver with special reference to the localisation of putative plasma membrane marker enzymes. Eur $J$ Biochem 1980;104:305-11.

7 Peters TJ. Analytical subcellular fractionation of jejunal biopsy specimens; methodology and characterisation of the organelles in normal tissue. Clin Sci Mol Med 1976; $51: 557-74$.

${ }^{8}$ Leighton F, Poole B, Beaufay H, Baudhuin P, Coffey JW, Fowler S, De Duve C. The large-scale separation of peroxisomes, mitochondria and lysosomes from livers of rat injected with Triton WR1339. J Cell Biol 1968;37: 482-513.

${ }^{9}$ Bjorntorp P, Bjorkerud S, Schersten T. Subcellular fractionation of human liver. Biochim Biophys Acta 1965;111:375-83.

${ }^{10}$ Selden C, Seymour CA, Peters TJ. Activities of some freeradical scavenging enzymes and glutathione concentrations in human and rat liver and their relationship to the pathogenesis of tissue damage in iron overload. Clin Sci $1980 ; 58: 211-9$.

${ }^{11}$ Tilleray J, Peters TJ. Analytical subfractionation of microsomes from the liver of control and Gunn strain rats. Biochem Soc Trans $1976 ; 4: 248-50$.

${ }^{12}$ Solyom A, Trams EG. Enzyme markers in characterization of isolated plasma membranes. Enzyme 1972;13:329-72.

${ }^{13}$ Evans WH. A biochemical dissection of the functional polarity of the plasma membrane of the hepatocyte. Biochim Biophys Acta 1980;604:27-64.

${ }^{14}$ Selden C, Wootton AM, Moss DW, Peters TJ. Analytical subcellular fractionation studies on different cell types isolated from normal rat liver. Clin Sci Mol Med 1978; $55: 423-7$.

${ }^{15}$ Wootton AW, Neale G, Moss DW. Some properties of alkaline phosphatases in parenchymal and biliary tract cells separated from rat liver. Clin Chim Acta 1975;61: 183-90.

${ }^{16}$ Knook DL, Blansjaar N, Sleyster EC. Isolation and characterization of Kupffer and endothelial cells from the rat liver. Exp Cell Res 1977;109:317-29.

${ }^{17}$ Bojar H, Basler M, Fuchs F, Dreyfurst R, Staib W, Broelsch C. Preparation of parenchymal and nonparenchymal cells from adult human liver-morphological and biochemical characteristics. J Clin Chem Clin Biochem 1976;14:527-32.

18 Barton R, Lloyd JB. Latency of some glycosidases of rat liver lysosomes. Biochem J 1976;160:631-8.

19 Amar-Costesec $A$, Wibo $M$, Thinès-Sempoux $D$, Beaufay HP, Berthet J. Analytical study of microsomes and isolated subcellular membranes from rat liver. IV Biochemical, physical and morphological modifications of microsomal components induced by digitonin, EDTA and pyrophosphate. J Cell Biol 1974;62:717-45.

20 Mitropoulos KA, Venkatesan S, Balasubramanian S, Peters TJ. The submicrosomal localisation of 3-hydroxy3-methylglutaryl coenzyme A reductase, cholesterol $7 a$ hydroxylase and cholesterol in rat liver. Europ J Biochem $1978 ; 82: 419-29$.

${ }^{21}$ Wibo M, Amar-Costesec A, Berthet J, Beaufay H. Electron microscope examination of subcellular fractions. III Quantitative analysis of the microsomal fractions isolated from rat liver. J Cell Biol 1971;51:52-71.

${ }^{22}$ Seymour CA, Peters TJ. Changes in hepatic enzymes and organelles in alcoholic liver disease. Clin Sci Mol Med $1978 ; 55: 383-9$

${ }^{23}$ Dawson J, Seymour CA, Peters TJ. Gilbert's syndrome: analytical subcellular fractionation of liver biopsy specimens. Enzyme activities, organelle pathology and evidence for subpopulations of the syndrome. Clin Sci 1979;57:491-7.

${ }^{24}$ Peters TJ, Jenkins W, Dubowitz V. Subcellular fractionation studies on hepatic tissue from a patient with Pompe's disease (type II glycogen storage disease). Clin Sci 1980;59:1-12.

${ }^{25}$ Scott J, Jenkins W, Smith GP, Peters TJ. Application of analytical subcellular fractionation in combination with enzymic microanalysis to the study of the hepatic organelle pathology of primary biliary cirrhosis and the response to low-dose D penicillamine. Clin Sci in press.

${ }^{26}$ Seymour CA, Neale G, Peters TJ. Lysosomal changes in liver tissue from patients with the Dubin-Johnson-Sprinz syndrome. Clin Sci Mol Med 1977;52:241-8.

27 Peters TJ, Seymour CA. The organelle pathology and demonstration of mitochondrial superoxide dismutase deficiency in two patients with Dubin-Johnson-Sprinz syndrome. Clin Sci Mol Med 1978;54:549-53.

${ }^{28}$ Seymour CA, Peters TJ. Organelle pathology in primary and secondary haemochromatosis with special reference to lysosomal changes. Br J Haematol 1979;40:239-53.

${ }^{29}$ Essner E, Novikoff AB. Human hepatocellular pigment and lysosomes. J Ultrastruct Res 1960;3:375-91.

${ }^{30}$ Toker C, Trevino N. Hepatic ultrastructure in chronic 
idiopathic jaundice. Arch Path 1965;80:456-60.

31 Barth RF, Grimley PM, Berk PD, Bloomer JR, Howe RB. Excess lipofuschin accumulation in constitutional hepatic dysfunction (Gilbert's syndrome). Light and electron microscopic observations. Arch Path 1971;91:41-7.

32 Hers HG. a-Glucosidase deficiency in generalised glycogen storage disease (Pompe's disease). Biochem J 1963;86: 11-6.

${ }^{33}$ Munthe-Kaas AC, Berg T, Seljelid R. Distribution of lysosomal enzymes in different types of rat liver cells. Exp Cell Res 1976;99:146-54.

${ }^{34}$ Van Hoof F, Hers HG. The abnormalities of lysosomal enzymes in muco polysaccharidosis. Europ $J$ Biochem 1968;7:34-44.

${ }^{35}$ Goldberg L, Martin LE, Batchelor A. Biochemical changes in the tissues of animals injected with iron and phosphatase and other enzymes. Biochem J 1960;77: 252-62.

${ }^{36}$ Meijer AEFH, Willighagen RGJ. The activity of glucose-6phosphatase, adenosine triphosphatase, succinic dehydrogenase and acid phosphatase after dextran or polyvinylpyrrolidone uptake by liver in vivo. Biochem Pharm 1963;12:973-80.

37 Peters TJ, De Duve C. Lysosomes of the arterial wall. II Subcellular fractionation of aortic cells from rabbits with experimental atheroma. Exp Mol Path 1974;20 228-66.

38 Axline SG, Cohn ZA. In vitro induction of lysosomal enzymes by phagocytosis. J Exp Med 1970;131:1239-60.

39 De Duve C, Wattiaux R. Functions of lysosomes. Ann Rev Physiol 1966;28:435-92.

40 Mellors A, Tappel AL, Savant PL, Desai ID. Mitochondrial swelling and uncoupling of oxidative phosphorylation by lysosomes. Biochim Biophys Acta 1967; 143:299-309.

11 Owen CA, Dickson ER, Goldstein NP, Baggenstoss AH, McCall JT. Hepatic subcellular distribution of copper in primary biliary cirrhosis. Mayo Clin Proc 1977;52: 73-80.

12 Benson GD. Hepatic copper accumulation in primary biliary cirrhosis. Yale J Biol Med 1979:52:83-8.

43 Porter H. Tissue copper proteins in Wilson's disease: intracellular distribution and chromatographic fractionation. Arch Neurol 1964;11:341-9.

${ }^{44}$ Goldfischer S, Sternlieb I. Changes in the distribution of hepatic copper in relation to progression of Wilson's disease (hepato lenticular degeneration). Am J Path 1968;53:883-901.

${ }^{45}$ Bessis M, Caroli J. A comparative study of haemochromatosis by electron microscopy. Gastroenterology $1959 ; 37: 538-49$.

46 Iancu TC, Neustein HB. Ferritin in human liver cells of homozygous beta thalassaemia: ultrastructural observations. Br J Haematol 1977; 37:527-35.

47 Peters TB, Selden C, Seymour CA. Lysosomal disruption in the pathogenesis of hepatic damage in primary and secondary haemochromatosis. Ciba Fnd Symp 1977;51: 317-29.

${ }^{48}$ Selden C, Owen M, Hopkins JMP, Peters TJ. Studies on the concentration and intracellular localisation of iron proteins in liver biopsy specimens from patients with iron overload with special reference to their role in lysosomal disruption. Br J Haematol 1980;44:593-603.

49 Fong K-L, McCay PB, Pover JL, Keele BB, Misra H. Evidence that peroxidation of lysosomal membranes is initiated by hydroxyl free radicals produced during flavin enzyme activity. J Biol Chem 1973;248:7792-7.

${ }^{50}$ Bors W, Saran M, Lengfelder E, Spöttl R, Michell C. The relevance of the superoxide anion radical in biological systems. Curr Top Rad Res Quart 1974;9:247-309.
${ }^{51}$ Halliwell B. Superoxide dependent formation of hydroxyl radicals in the presence of iron chelates: is it a mechanism for hydroxyl radical production in biochemical systems? FEBS Letters 1978 ;92:321-6.

52 Peters TJ, Seymour CA. Human tissue analysis by analytical subcellular fractionation techniques in combination with enzymic microassays. In: Goldberg DM, ed. Enzymes in health and disease. Basel: Karger, 1978:38-45.

53 Dawson J, Bryant MG, Bloom SR, Peters TJ. Subcellular fractionation studies of human gastric antrum. Characterization of gastrin, somatostatin and VIP storage granules and the principal organelles in normal tissue. Clin Sci 1980;59:1-6.

${ }^{54}$ Peters TJ, Jones PE, Wells G. Analytical subcellular fractionation of jejunal biopsy specimens: enzyme activities and organelle pathology and response to gluten withdrawal in patients with coeliac disease. Clin Sci Mol Med 1978;55:285-92.

${ }^{55}$ Cooper BT, Candy DCA, Harries JT, Peters TJ. Subcellular fractionation studies of the intestinal mucosa in congenital sucrase-isomaltase deficiency. Clin Sci 1979; 57:181-5.

56 Peters TJ, Jones PE, Wells G, Cook GC. Sequential enzyme and subcellular fractionation studies on jejunal biopsy specimens from patients with post-infective tropical malabsorption. Clin Sci 1979;56:479-86.

${ }^{57}$ Nicholson JA, Peters TJ. The subcellular localisation of peptide hydrolase activity in the human jejunum. Europ $J$ Clin Invest 1979;9:349-54.

58 Bryant MG, Dawson J, Bloom SR, Peters TJ. Separation of the gut hormone endocrine cell storage granules of human jejunum using subcellular fractionation. Gut $1980 ; 21: 177-80$.

59 Kane SP, Vincenti AC. Mucosal enzymes in human inflammatory bowel disease with reference to neutrophil granulocytes as mediators of tissue injury. Clin Sci 1979; 57:295-303.

${ }^{60}$ Dawson J, Bryant MG, Bloom SR, Peters TJ. Subcellular fractionation studies of human rectal mucosa. Biochemical characterisation of enteroglucagon, somatostatin and vasoactive intestinal polypeptide storage granules and the principal organelles. Clin Sci in press.

61 Peters TJ, Wells G, Brooksby IAB, Jenkins BS, WebbPeploe MM, Coltart DJ. Correlations of myocardial biochemistry and function in man: enzymic analysis of cardiac biopsy material from patients with valvular heart disease. Lancet 1976; : $269-70$.

62 Peters TJ, Wells G, Oakley CM, Brooksby IAB, Jenkins BS, Webb-Peploe MM, Coltart DJ. Enzymic analysis of endomyocardial biopsy specimens from patients with cardiomyopathies. Br Heart J 1978;12:1333-9.

${ }^{63}$ Fitchett DH, Wells G, Peters TJ. Analytical subcellular fractionation of human heart: a comparison of left and right ventricle with hypertrophic obstructive myopathic tissue. Cardiovas Res 1979;13:532-40.

${ }^{64}$ Fitchett DH, Coltart DJ, Littler WA, Leyland MJ, Trueman T, Gozzard DI, Peters TJ. Cardiac involvement in secondary haemochromatosis: a catheter biopsy study and analysis of myocardium. Cardiovas Res in press.

${ }^{65}$ Dawson J, Peters TJ. Unpublished results.

${ }_{66}$ Martin F, Levi J, Slavin G, Peters TJ. Enzymic analysis of human skeletal muscle biopsy samples. Clin $\mathrm{Sci}$ in press.

67 Mashiter K, Peters TJ. Analytical subcellular fractionation of human pituitary: characterisation of the organelles and hormone-containing granules from normal and adenomatous tissue. Clin Sci Mol Med 1978;55: 13-14P.

68 Dawson J, Peters TJ. Unpublished results.

${ }^{69}$ Kane SP, Peters TJ. Analytical subcellular fractionation of 
human granulocytes with reference to the localization of vitamin B12 binding proteins. Clin Sci Mol Med 1975; 49:171-82.

"Segal AW, Peters TJ. Analytical subcellular fractionation of human granulocytes with special reference to the localization of enzymes involved in microbicidal mechanisms. Clin Sci Mol Med 1977;52:429-42.

${ }^{\prime \prime}$ Segal AW, Peters TJ. Analytical subcellular fractionation of neutrophils from patients with chronic granulomatous disease. Demonstration of the enzyme defect in four cases. Quart J Med 1978;47:213-20.

72 Rustin GJS, Wilson PD, Peters TJ. Studies on the subcellular localisation of human neutrophil alkaline phosphatase. J Cel! Sci 1979;36:401-12.

${ }^{73}$ Rustin GJS, Peters TJ. Studies on the subcellular organelles of neutrophils in chronic granulocytic leukaemia with special reference to alkaline phosphatase. Br J Haematol $1979 ; 41: 533-43$.

" Smith GP, Peters TJ. Studies on the activities, kinetic properties and subcellular localisation of cyclic AMP phosphodiesterase in human neutrophil leukocytes. Clin Chim Acta 1980;103:193-201.

75 Hughes KT, Davies M, Andrew PW, Peters TJ. Analytical fractionation of subcellular organelles from human peripheral monocytes with particular reference to their neutral proteinase content. Biochem Soc Trans in press.

7" Shah T, Webster D, Peters TJ. Analytical subcellular fractionation with enzymic microassay of human peripheral blood lymphocytes. Clin Sci in press.

77 Peters TJ, Neale G, Heath JR. Effect of bile duct ligation on the activities of liver and serum enzymes of rats. Clin Sci Mol Med 1975;48:307-13.

is Soulé J-C. Neale G, Peters TJ. Functional and biochemical evidence of damage to enterocytes induced by Triparanol. Clin Sci Mol Med 1976;51:19-25.

7: Neerunjun JS, Dubowitz V, Peters TJ. Analytical subcellular fractionation and enzymic analysis of dystrophic mouse skeletal muscle. Biochem Soc Trans 1978;6:12668.
* Bhuyan UN, Welbourn CRB, Evans DJ, Peters TJ. Biochemical studies of the isolated rat glomerulus and the effects of puromycin amino nucleoside administration. Br J Exp Path 1980;61:69-75.

"1 Batt RM, Bush BM, Peters TJ. Naturally occurring enteropathy in the dog resembling chronic tropical sprue. Gut 1979;20:A441.

*2 Batt RM, Bush BM, Peters TJ. Biochemical changes in the jejunal mucosa of dogs with naturally occurring exocrine pancreatic insufficiency. Gut 1979;20:709-15.

*:3 Beaufay $\mathrm{H}$. La centrifugation en gradient de densité. Thèse d'Agrégation de L'Enseignement Supérieur. Louvain: Université Catholique de Louvain, 1966.

*1 Gregor HD. A new method for the rapid separation of cell organelles. Analyt Biochem 1977;82:255-7.

*. Batt RM, Mann LC. Analytical subcellular fractionation of dog liver. An evaluation of preformed Percoll and reorientating sucrose density gradients. Clin Sci 1980: 59:25P.

*6 Jenkins WJ, Clarkson E, Milsom J. Sherlock S. Simple analytical subcellular fractionation of liver biopsies with Percoll. Clin Sci 1979;57:28P.

* : Peters TJ, Heath JR, Wansbrough-Jones MH, Doe WF. Enzyme activities and properties of lysosomes and brush borders in jejunal biopsies from control subjects and patients with coeliac disease. Clin Sci Mol Med 1975:48 259-67.

* Jenkins WJ, Peters TJ. Mitochondrial enzyme activities in liver biopsies from patients with alcoholic liver disease. Gut 1978;19:341-4.

: Jenkins WJ, Peters TJ. Selectively reduced hepatic acetaldehyde dehydrogenase in alcoholics. Lancet 1980;1:628-9.

Requests for reprints to: Dr TJ Peters, Division of Clinical Cell Biology, Clinical Research Centre, Watford Road, Harrow, Middlesex HA1 3UJ. 